\title{
Al-Er-V (Aluminum-Erbium-Vanadium)
}

\section{Raghavan}

Recently, an isothermal section at $500{ }^{\circ} \mathrm{C}$ was reported for this ternary system by [2010Yan]. It depicts the previously-known ternary compound $\mathrm{Al}_{43} \mathrm{Er}_{6} \mathrm{~V}_{4}$.

\section{Binary Systems}

The Al-Er phase diagram [Massalski2] depicts the following intermediate phases: $\mathrm{Al}_{3} \mathrm{Er}\left(L 1_{2}, \mathrm{AuCu}_{3}\right.$-type cubic), $\mathrm{Al}_{2} \mathrm{Er}$ (C15, $\mathrm{MgCu}_{2}$-type cubic), AlEr (AlEr-type

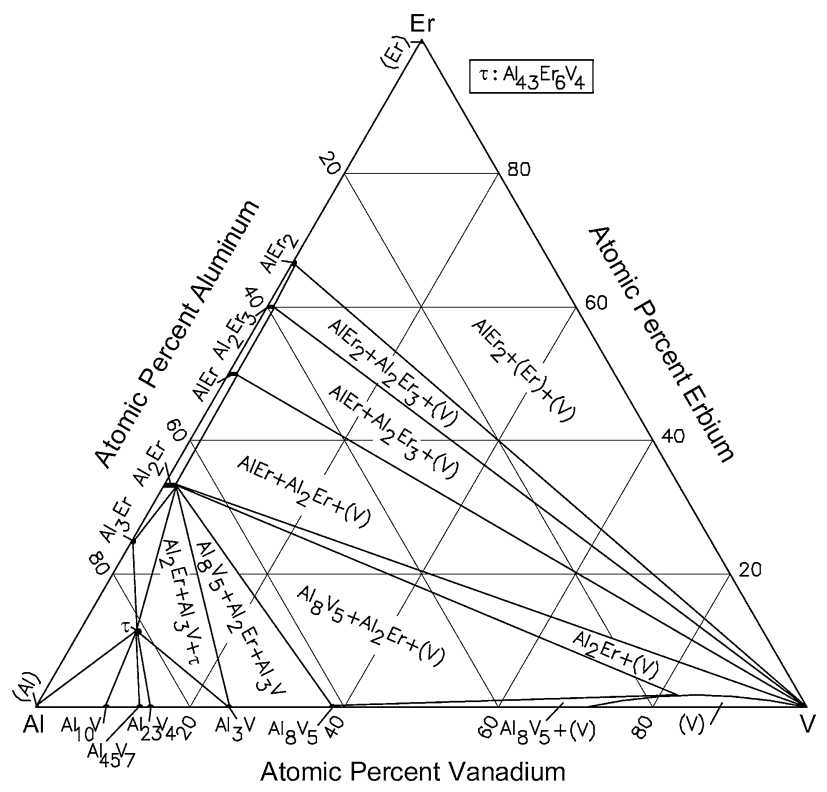

Fig. 1 Al-Er-V isothermal section at $500{ }^{\circ} \mathrm{C}$ [2010Yan]. Narrow two-phase regions are omitted orthorhombic), $\mathrm{Al}_{2} \mathrm{Er}_{3}\left(\mathrm{Zr}_{3} \mathrm{Al}_{2}\right.$-type tetragonal), and $\mathrm{AlEr}_{2}$ ( $C 23, \mathrm{Co}_{2} \mathrm{Si}$-type orthorhombic). The Al-V phase diagram [2004Gon, 2010Yan, Massalski2] depicts five intermetallic compounds: $\mathrm{Al}_{8} \mathrm{~V}_{5}\left(D 8_{2}, \mathrm{Cu}_{5} \mathrm{Zn}_{8}\right.$-type cubic), $\mathrm{Al}_{3} \mathrm{~V}$ ( $D 0_{22}, \mathrm{TiAl}_{3}$-type tetragonal), $\mathrm{Al}_{23} \mathrm{~V}_{4}$ (hexagonal), $\mathrm{Al}_{45} \mathrm{~V}_{7}$ (monoclinic), and $\mathrm{Al}_{10} \mathrm{~V}$ (cubic). There are no intermediate phases in the Er-V system. Here, a liquid miscibility gap is present with a monotectic reaction at $1870{ }^{\circ} \mathrm{C}$.

\section{Ternary Isothermal Section}

With starting metals of $99.99 \% \mathrm{Al}, 99.99 \%$ Er and $99.9 \%$ $\mathrm{V}$, [2010Yan] arc-melted under Ar atm 58 binary and ternary alloys. The alloys were given a final anneal at $500{ }^{\circ} \mathrm{C}$ for $240 \mathrm{~h}$ and quenched in liquid nitrogen. The phase equilibria were studied with optical and scanning electron microscopy and $\mathrm{x}$-ray powder diffraction. The isothermal section constructed at $500{ }^{\circ} \mathrm{C}$ by [2010Yan] is shown in Fig. 1. The ternary compound $\mathrm{Al}_{43} \mathrm{Er}_{6} \mathrm{~V}_{4}$ (denoted $\tau$; $\mathrm{Al}_{43} \mathrm{Ho}_{6} \mathrm{Mo}_{4^{-}}$ type hexagonal, Pearson symbol $h P 106$, space group $\mathrm{Pb}_{3} / \mathrm{mcm}$, lattice parameters $a=1.08967 \mathrm{~nm}$ and $c=$ $1.76236 \mathrm{~nm}$ ) is present. The $\mathrm{Al}-\mathrm{Er}$ compounds $\mathrm{Al}_{2} \mathrm{Er}$, AlEr and $\mathrm{Al}_{2} \mathrm{Er}_{3}$ dissolve up to about $1-2$ at.\% V. The solubility of the third component in the other binary compounds is negligible.

\section{References}

2004Gon: W. Gong, Y. Du, B. Huang, R. Schmid-Fetzer, C. Zhang, and H. Xu, Thermodynamic Reassessment of the Al-V System, Z. Metallkd., 2004, 95(11), p 978-986

2010Yan: Z. Yan, Y. Zhan, H. Mo, Y. Du, and H. Xu, Determination of the Phase Equilibria in the Al-Er-V Ternary System at 773 K, J. Alloys Compd., 2010, 503, p 61-64 